\title{
Enhancing control of eastern redcedar through individual plant ignition following prescribed burning
}

\author{
DAVID M. ENGLE AND J.F. STRITZKE
}

Authors are with the Oklahoma Agricultural Experiment Station, Oklahoma State University, Stillwater, Okla.
74078

Abstract

Fire-scorched crowns of live eastern redcedar (Juniperus virginiana $\mathrm{L}$.) were ignited using a propane torch in 3 studies to quantify the efficacy and to determine the feasibility of the technique as a follow-up treatment for killing trees that survived prescribed burns. In the first study, we ignited 98 fire-scorched, live trees 20 to 64 days following a prescribed burn. Igniting scorched trees in several positions killed $90 \%$ of the crown and two-thirds of the trees regardless of tree size. Logistic regression models indicated reburning was more effective on trees highly damaged after prescribed burning. In the second study, one person equipped with a self-contained backpack propane burner used single-point ignition to treat an average of 1 tree every 17 seconds (range 11 to 20 seconds) on 0.25-ha plots. Effectiveness of the single-point ignition declined with increasing tree size. In the third study, the average time required to burn a tree was 19 seconds in eight 32-ha pastures. Cost in this field-scale study for labor, propane, fuel, and equipment depreciation was $\$ \mathbf{\$ 0} \mathbf{0 3}$ /ignited tree.

Key Words: brush control, Juniperus virginiana $\mathbf{L}$.

Eastern redcedar (Juniperus virginiana L.) is invading grasslands and forests of the central United States at an exponential rate (Snook 1985). Eastern redcedar is not a sprouting species, so treatments that destroy above-ground portions will kill the tree. Herbicide and mechanical treatments for individual juniper trees have been suggested for juniper-dominated rangelands throughout the western United States (Ueckert and Whisenant 1982, Johnsen and Dalen 1984, Van Pelt and West 1990).

Prescribed burning is an economically attractive alternative for controlling eastern redcedar because it effectively kills seedlings and small trees (Bernardo et al. 1988, Engle et al. 1988). However, when fuel loading is insufficient or the trees are very large, only lower branches are scorched and trees are not killed. Individual tree burning may offer an alternative to mechanical or chemical treatments for follow-up control. Burning individual small, nonsprouting juniper in open stands was successfully demonstrated in Arizona (Jameson 1966). The objective of these studies was to quantify the efficacy and to determine the feasibility of igniting partially scorched eastern redcedar trees which survived prescribed burns.

\section{Methods and Materials}

\section{Equipment}

The torch assembly consists of an LPG vapor torch $(1900 \mathrm{~kJ} / \mathrm{hr})$ with a $0.7-\mathrm{m}$ handle, a 3.1-m LPG hose, and a 11-liter fuel cylinder ${ }^{1}$. The assembly is carried on a back pack frame of alumi-

\footnotetext{
The authors thank Dr. P.L. Claypool for assistance and advice in statistical analysis.

This is Journal Article J-5967 of the Agricultural Experiment Station.

Manuscript accepted 15 Feb. 1992.

'Flame Engineering, Inc. of LaCrosse, Kan. provided the torch kit.
}

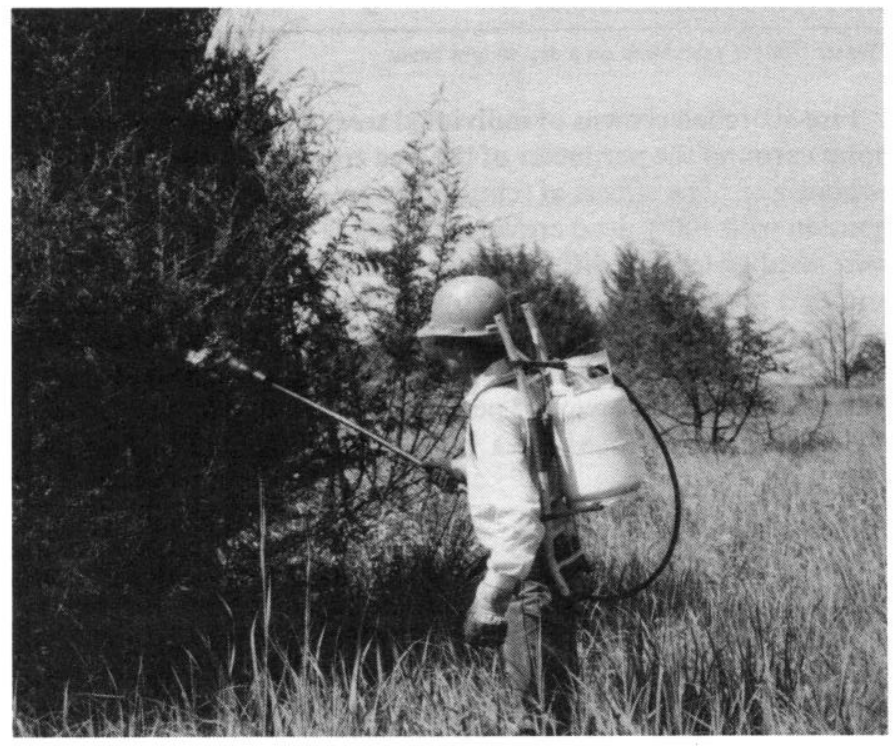

Fig. 1. The torch assembly used for igniting individual eastern redcedar trees that are partially scorched in prescribed burns.

num tubing with nylon webbing (Fig. 1). Total weight when filled with propane is approximately $16 \mathrm{~kg}$. Operated as we used it, the fuel cylinder will supply fuel for approximately 4 hours of burning $(470 \mathrm{~kJ} / \mathrm{hr})$. The torch assembly does not require a regulator or pressure gauge. Desired flame length is obtained by adjusting the flow valve.

\section{Study 1: Individual Trees}

To evaluate conditions under which reburning is effective, we ignited 98 fire-scorched, live trees with the propane burner 20 to 64 days following a prescribed burn in tallgrass prairie. The study area was located in Payne County on a loamy prairie range site with relatively level topography and : lopes less than $5 \%$. The study area, approximately 60 ha, was burned with a headfire on 14 April 1988. Fine fuel loading for the headfire was discontinuous and averaged 2,000 to $3,000 \mathrm{~kg} / \mathrm{ha}$. Ambient air temperature during the headfire was $24^{\circ} \mathrm{C}$, relative humidity was $40 \%$, and wind speed averaged 8 $\mathrm{km} / \mathrm{hr}$. Density of eastern redcedar on the area was 370 trees/ ha. Crown scorch on eastern redcedar from the headfire averaged about $90 \%$ and tree kill averaged about $55 \%$. Crown scorch on the 98 trees selected to reburn ranged from 5 to $90 \%$ and averaged $52 \%$.

Fire-scorched trees were categorized into 3 height classes: $<1.5$ $\mathrm{m}, 1.5$ to $2.5 \mathrm{~m}$, and 2.5 to $5.0 \mathrm{~m}$. Damage to tree crowns was divided into 2 types: crown scorch (percent crown retaining dead leaves) and dead crown (sum of percent crown scorch and percent 
crown with leaves consumed by fire). Table 1 presents the weather conditions and crown characteristics recorded immediately before ignition.

Table 1. Conditions in study 1 under which crowns of 98 individual eastern redcedar trees were ignited at different time intervals following a pescribed fire on 14 April 1988.

\begin{tabular}{lrrrl}
\hline \hline & Min. & Max. & Mean & SE \\
\hline Air temperature, ${ }^{\circ} \mathrm{C}$ & 13 & 33 & 27 & 0.4 \\
Relative humidity, \% & 28 & 70 & 43 & 1 \\
Wind speed, $\mathrm{km} / \mathrm{hr}^{\text {Water content of dead leaves, \%1 }}$ & 0 & 16 & 9 & 0.3 \\
Water content of live leaves, \%1 & 1 & 18 & 7 & 0.4 \\
Crown scorch before reburning, \% & 48 & 267 & 134 & 4 \\
Dead crown before reburning, \% & 5 & 90 & 52 & 2 \\
\hline
\end{tabular}

'Water content calculated on a dry-weight basis.

Fire-scorched crowns of individual trees were ignited at several points around the perimeter of the tree crown to ensure sustained combustion. The effects of reburning were evaluated 60 days after ignition with $100 \%$ dead crown recorded as tree kill. Paired $t$-tests were used to test for differences in amount of dead crown before and after reburning. Logistic stepwise regression was used to relate weather (air temperature, relative humidity, and wind speed), leaf water content (live leaves and dead leaves), and crown damage (percent scorched crown and percent dead crown) to the probability of killing individual trees by reburning (SAS Institute Inc. 1989).

\section{Study 2: Small Plots}

The efficacy of single-point ignition of fire-scorched trees was evaluated on eight 0.25 -ha $(50 \times 50 \mathrm{~m})$ plots within a tallgrass prairie. The study area was in Payne County on shallow prairie and red clay prairie range sites with slopes of 5 to $10 \%$. The study area, about 32 ha, was burned 5 April 1989. Fine fuel loading was discontinuous and averaged 5,000 to $6,000 \mathrm{~kg} / \mathrm{ha}$ with some areas supporting less than $2,000 \mathrm{~kg} / \mathrm{ha}$. Ambient air temperature at the time of the prescribed burn was $17^{\circ} \mathrm{C}$, relative humidity was $28 \%$, and wind speed averaged $13 \mathrm{~km} / \mathrm{hr}$. Most of the area was burned with a headfire. Crown scorch in the study area averaged about $90 \%$ and tree kill averaged about $50 \%$. The plots were on relatively level terrain and provided easily accessible travel routes. Density of scorched, live trees in these plots varied from 40 to 100 trees/plot.

Only 1 ignition point per tree was used in this study to reduce the time allotted to igniting each crown. The ignition point was on the windward side of the tree. Trees were categorized into 3 height classes: $>1.5 \mathrm{~m}, 1.5$ to $2.5 \mathrm{~m}$, and 2.5 to $5.0 \mathrm{~m}$. Weather conditions (air temperature, relative humidity, and wind speed) were recorded and eastern redcedar leaf water content (live leaves and dead leaves) was sampled from 5 trees/plot immediately before burning each plot. Effects of reburning were evaluated 60 days after ignition with $100 \%$ dead crown recorded as tree kill. Stepwise multiple regression was used to relate weather and leaf water to tree kill resulting from reburning.

\section{Study 3: Large Plots}

Operational effectiveness was evaluated on eight 32-ha pastures located in the Cross Timbers of Payne County. The primary upland range sites in the study area were sandy savannah and shallow savannah. These sites have slopes of 1 to $8 \%$ and are dissected by steep gullies and drainageways up to $10 \mathrm{~m}$ deep. Vegetation in these pastures was a mixture of tallgrass prairie and upland hardwood forest. The dominant hardwoods had been controlled with herbicides in 1983 and many of the smaller eastern redcedar had been controlled by prescribed burning in 1985, 1986,
1987, and 1990 (Stritzke et al. 1991). Rough topography, dense brush, and woody debris reduced the accessibility of travel routes.

Scorched, live trees were ignited 45 days to 130 days after prescribed burns conducted in early April of 1990. Density of scorched, live trees ranged from 20 to 128 / ha. Burning was limited to periods when wind speed was less than $16 \mathrm{~km} / \mathrm{hr}$ and ignition was on the windward side of the tree crown. After several hours of burning, operators learned that several ignition points were required on larger trees. This resulted in operators igniting trees with the aim of optimizing ignition of scorched crowns/time outlay.

\section{Results and Discussion}

\section{Study 1}

In preliminary trials, we observed that effectiveness of reburning was greatly reduced when wind speed exceeded $16 \mathrm{~km} / \mathrm{hr}$, apparently because the wind tilted the flame and heated air away from the upper portions of the juniper crown. Thus, the results from this study are applicable to conditions with wind speed less than 16 $\mathrm{km} / \mathrm{hr}$.

The amount of dead crown after reburning averaged about $90 \%$ regardless of tree size (Fig. 2). Tree kill after reburning was 67, 67,

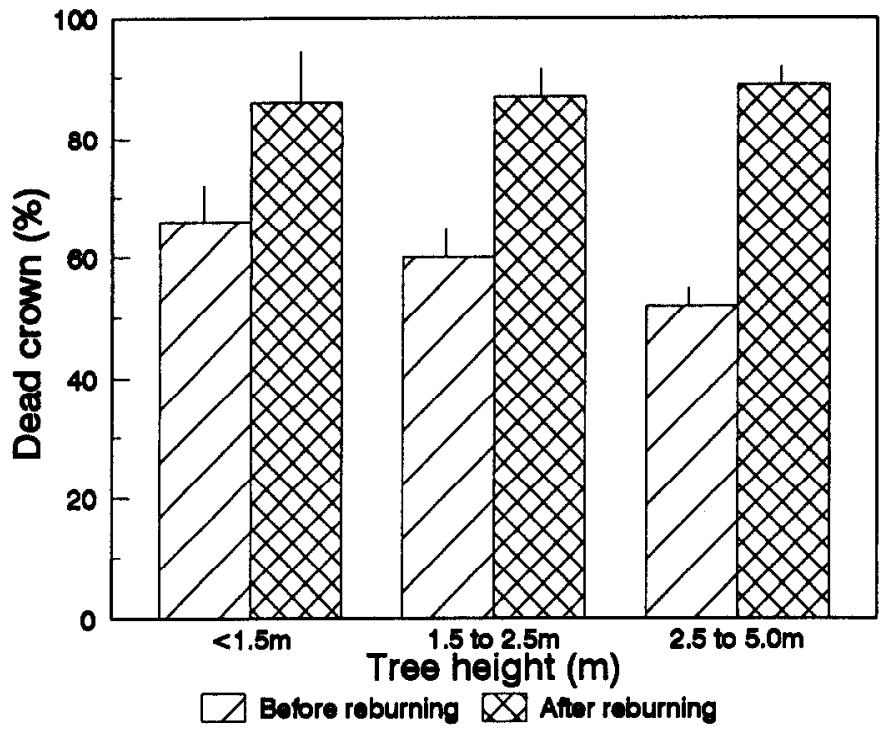

Fig. 2. The amount of dead crown in individual eastern redcedar trees in study 1 before and after igniting the scorched portions of the crowns. Vertical bars represent one-half standard error. Values for before and after burning are different $(P<0.01)$ within height classes.

and $62 \%$, respectively, for small, medium, and large trees. The amount of dead crown or the amount of scorched crown appeared in logistic regression models of tree kill resulting from reburning (Table 2). This indicates that reburning was more effective on trees highly damaged with prescribed burning. The model of kill of large trees indicates reburning was more effective with higher air temperatures and drier leaves.

\section{Study 2}

One person equipped with a self-contained backpack propane burner ignited an average of 1 tree every 17 seconds (range 11 to 20 seconds) on the 0.25 -ha plots. Reburning with 1 ignition point killed $77 \%$ of small trees, $55 \%$ of medium trees, and $26 \%$ of large trees. The reduced effectiveness on larger trees in these plots compared to study 1 was attributed to reduced crown ignition following the single-ignition point compared to multiple-ignition points per tree used in study 1 .

In this study, air temperature was related to kill of small and 
Table 2. Logistic regression models ${ }^{1}$ of tree kill as a result of burning crowns of fire-scorched eastern redcedar in study 1 .

\begin{tabular}{lccc}
\hline \hline Variable & $\begin{array}{c}\text { Parameter } \\
\text { estimate }\end{array}$ & $P>\chi^{2}$ & $\begin{array}{c}\text { Rank } \\
\text { correlation }\end{array}$ \\
\hline Small trees $(<1.5 \mathrm{~m})(\mathrm{n}=9)$ & & & 0.89 \\
$\quad$ Scorched crown, \% & -0.186 & 0.19 & \\
$\quad$ Intercept & 10.676 & 0.17 & 0.72 \\
Medium trees (1.5 to 2.5 m) (n=35) & & & \\
$\quad$ Dead crown, \% & -0.067 & 0.01 & \\
Intercept & 3.243 & 0.02 & \multirow{2}{*}{0.66} \\
Large trees (2.5 to 5.0 m) (n=54) & & & \\
$\quad$ Air temperature, ${ }^{\circ} \mathrm{C}$ & -0.211 & 0.03 & \\
Dead crown, \% & -0.028 & 0.06 & \\
Water in dead leaves, \% & 0.182 & 0.08 & \\
Intercept & 4.785 & 0.09 & \\
\hline
\end{tabular}

The probability of killing an individual tree is $p=1 /(1+\exp (\hat{y}))$, where $p$ is the probability of obtaining a kill, and $\hat{y}$ is the fitted regression value based on the parameter estimates. All models are significant at $P<0.02$.

${ }^{2}$ The Goodman-Kruskal Gamma rank correlation.

medium trees (Table 3) whereas in study 1 , air temperature was related only to kill of large trees. Differences between result of study 1 and study 2 may be related to the poor tree kill of large trees in study 2 resulting from igniting crowns at only a single point.

Table 3. Stepwise multiple regression models ${ }^{1}$ of tree kill (percent) as a result of burning crowns of fire-scorched eastern redcedar on eight 0.25-ha plots in study 2 .

\begin{tabular}{|c|c|c|c|}
\hline Variable & $\begin{array}{c}\text { Parameter } \\
\text { estimate }\end{array}$ & $P>F$ & Model R2 \\
\hline Small trees $(<1.5 \mathrm{~m})$ & & & 0.48 \\
\hline Air temperature, ${ }^{\circ} \mathrm{C}$ & 3.1 & 0.06 & \\
\hline Intercept & -4.6 & 0.90 & \\
\hline Medium trees (1.5 to $2.5 \mathrm{~m})$ & & & 0.37 \\
\hline Air temperature, ${ }^{\circ} \mathrm{C}$ & 1.9 & 0.11 & \\
\hline Intercept & 3.8 & 0.90 & \\
\hline
\end{tabular}

'Models significant at $P<0.06$ and $P<0.08$, respectively for small and medium trees. No variable met the 0.15 significance level for entry into the model for large trees.

\section{Study 3}

Time required to ignite a tree averaged 19 seconds (range 10 to 55 seconds) on the 32-ha pastures. Burning sessions (periods with uninterrupted burning) within a pasture ranged from $21 \mathrm{~min}$ to $>9.5$ hours, with entire pastures treated in as few as 3 burning sessions to as many as 11 sessions. Air temperatures during the burning sessions averaged $30^{\circ} \mathrm{C}$ but were as high as $39^{\circ} \mathrm{C}$, so operators rested frequently or were periodically relieved by a substitute operator.

Burning costs attributed to labor, propane fuel, and equipment depreciation amounted to $\$ 566$ for the entire 260 ha area (Table 4). Cost per treated tree (trees surviving the prescribed burn) was $\$ 0.03 /$ tree. These treatment costs are comparable to costs of chemical and mechanical control of smaller trees and less on trees taller

Table 4. Summary of costs for burning scorched crowns of eastern redcedar trees on eight 32-ha pastures in study 3.

\begin{tabular}{lc}
\hline \hline Activity & Cost (\$) \\
\hline Labor & \\
$\quad 97$ hours @ \$5/hr & 485.00 \\
Fuel, propane & \\
$\quad 73 \mathrm{~kg} @ \$ 0.70 / \mathrm{kg}$ & 51.10 \\
Equipment & 30.00 \\
$10 \%$ annual depreciation on $\$ 300$ & 566.10 \\
Total variable cost, 256 ha & 2.21 \\
Cost per ha & 0.03 \\
Cost per ignited tree & \\
\hline
\end{tabular}

than $2.5 \mathrm{~m}$ (Stritzke and Bidwell 1989).

Cost of labor, the major component of costs for individual plant ignition, varies with tree density, tree size, undergrowth, and slope (Van Pelt and West 1990), so the results should be interpreted in view of the conditions at our study site. It is noteworthy, however, that time outlay per tree ( $19 \mathrm{sec} /$ tree) was similar to that of study 2 ( $17 \mathrm{sec} /$ tree) even though the 2 studies were conducted in considerably different topography and vegetation.

\section{Management Implications}

Ignition of scorched trees can begin several weeks after a broadcast fire when scorched tree leaves dried to equilibrium with atmospheric moisture. The best results were achieved by burning when wind speed was $<8 \mathrm{~km} / \mathrm{hr}$ and when air temperature was $>26^{\circ} \mathrm{C}$, and by igniting several points on the lower branches of the windward side of larger trees. Other conditions appear to have little influence on results, probably because dry scorched leaves are excellent fuel. The kill rate is high under a wide range of conditions.

Crown ignition may be used repeatedly on partially scorched living trees because crowns may be reignited after about 2 weeks when the additional crown scorch becomes evident. Multiple follow-up burning cycles could eliminate living juniper trees, but with a decreasing cost efficiency because labor requirements per tree would increase as density of live trees decreases. Managers should be aware that eliminating all live eastern redcedar from management units is unlikely to be biologically or economically justified (Bernardo et al. 1988, Scifres 1987).

Because new herbaceous growth following spring burns remains green throughout most of the summer, the danger of uncontrolled fire within the pasture is minimal with this follow-up treatment. We burned through the first week in August following the initial broadcast burn in study 3 with no ground fires within the burned pasture. However, a spot fire in an adjacent unburned pasture in early July resulted from a firebrand. Therefore, caution should be exercised when burning near pastures containing dry fine fuel because firebrands can ignite spot fires up to $300 \mathrm{~m}$ when air temperature rises above $27^{\circ} \mathrm{C}$ (Bunting and Wright 1974).

\section{Literature Cited}

Bernardo, D.J., D.M. Engle, and F.T. McCollum. 1988. An economic assessment of risk and returns from prescribed burning on tallgrass prairie. J. Range Manage. 41:171-183.

Bunting, S.C., and H.A. Wright. 1974. Ignition capabilities on nonflaming firebrands. J. Forest. 72:646-649.

Engle, D.M., J.F. Stritzke, and P.L. Claypool. 1988. Effect of paraquat plus prescribed burning on eastern redcedar (Juniperus virginiana). Weed Tech. 2:172-174

Jameson, D.A. 1966. Juniper control by individual tree burning. USDA Forest Serv. Res. Note RM-71.

Johnsen, T.N., Jr., and R.S. Dalen. 1984. Controlling individual junipers and oaks with pelleted picloram. J. Range Manage. 37:380-384.

SAS Institute Inc. 1989. SAS/STAT user's guide, version 6, fourth edition. SAS Institute, Inc., Cary, N.C.

Scifres, C.J. 1987. Decision-analysis approach to brush management planning: ramifications for integrated range resources management. J. Range Manage. 40:482-490.

Snook, E.C. 1985. Distribution of eastern redcedar on Oklahoma rangelands. p. 45-52. In: R.W. Wittwer and D.M. Engle, eds. Proc. Eastern Redcedar in Okla. Conf. Coop. Ext. Serv., Div. Agr., Oklahoma State Univ. E-849.

Stritzke, J.F., and T.G. Bidwell. 1989. Eastern redcedar and its control. OSU Extension Facts. No. 2850. Coop. Ext. Serv. Okla. State Univ.

Stritzke, J.F., and D.M. Engle, and F.T. McCollum. 1991. Vegetation management in the Cross Timbers: Response of woody species to herbicides and burning. Weed Tech. 5:400-405.

Ueckert, D.N., and S.G. Whisenant. 1982. Individual plant treatments for controlling redberry juniper seedlings. J. Range Manage. 35:419-423.

Van Pelt, N.S., and N.E. West. 1990. Effects of manual application method on application time, thoroughness, and tebuthiuron outlays. J. Range Manage. 43:39-42. 